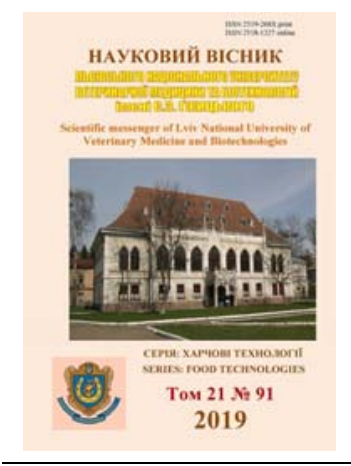

\author{
Науковий вісник Яьвівського національного університету \\ ветеринарної медицини та біотехнологій імені С.3. Гжицького. \\ Серія: Харчові технології
}

\author{
Scientific Messenger of Lviv National University
} of Veterinary Medicine and Biotechnologies.

Series: Food Technologies

ISSN 2519-268X print

https://nvlvet.com.ua/index.php/food

doi: $10.32718 /$ nvlvet-f9109

UDC 637.5.04/.07: 637.52

\title{
Biological efficiently of cooked sausages protein
}

\author{
O. Fursik, I. Strashynskyi, V. Pasichnyi, R. Svyatnenko \\ National University of Food Technologies, Kyiv, Ukraine
}

Article info

Received 18.01.2019

Received in revised form 15.02.2019

Accepted 18.02.2019

National University of Food Technologies,

Volodymyrska Str., 68

Kyiv, 01601, Ukraine.

Tel.: +38-098-837-80-39

E-mail:fursikoksana@gmail.com

Fursik, O., Strashynskyi, I., Pasichnyi, V., \& Svyatnenko, R. (2019). Biological efficiently of cooked
sausages protein. Scientific Messenger of Lviv National University of Veterinary Medicine and Biotechnologies. Series: Food Technologies, 21(91), 48-53. doi: 10.32718/nvlvet-f9109

Food proteins, besides being used as sources of energy and providing the body with amino acids for the protein synthesis, are important biological objects that help maintain the overall health of a person, participate in the growth and development of the organism, and the functioning of cellular metabolism. Due to the ability of maintaining a balance between anabolic and catabolic metabolism, industrial proteins have achieved the status of a biologically active ingredient or substance that promotes health, which is associated with the placement of peptides or amino acids in the chain encoded in each protein. The article presents the data of conducted researches on the influence of created functional composition containing protein (FCP) of the given composition and properties on SCORE and indicators of biological efficiency of cooked sausages proteins. Biological value, as a criterion for evaluating the protein, is very important for determining the effectiveness of its use by the organism. The product's amino acid composition is one of the indicators of its biological value. As a result of the obtained data analysis on the study of the experimental cooked sausage's amino acid composition, it was found that the experimental samples using the FCP were balanced by the content of essential amino acids in comparison with the control sample. For a experimental sample number 1 using FCP in combination with red poultry compared to the control sample, the number of all essential amino acids is increased by an average of $67.2 \%$. For the experimental sample number 2 using FCP combined with mechanical deboned poultry meat (MDPM), there is a decrease in the number of amino acids such as lysine, valine, sulfur-containing (compared to the experimental sample number 1), the SCORE for which is less than $100 \%$. Calculating the indicator of biological value and comparative redundancy, and the coefficients of differentiation the amino acid composition (CDAAC) and utility, generalized the effect of $F C P$ on the biological efficiency of the product's protein. The use of FCP in the cooked sausages technology in the amount of $30 \%$ increases the biological value of experimental samples by an average of $3 \%$, utilitarian utilization rate - by $8.4 \%$, and reduces the comparative redundancy by an average of $50 \%, C D A A C-$ by $4 \%$ compared to the control sample. Replacement of the meat raw material developed by the FCP in the recipes of cooked sausages increases and balances the amino acid composition of the experimental samples.

Key words: biological efficiency of protein, cooked sausage, essential amino acids, functional composition containing protein, biological value, protein.

\section{Біологічна ефективність білків варених ковбас}

\author{
О.П. Фурсік, І.М. Страшинський, В.М. Пасічний, Р.С. Святненко
}

Національний університет харчових технологій, м. Київ, Украӥна

\footnotetext{
Харчові білки, крім того, що використовуються як джерела енергї $і$ забезпечують організм амінокислотами для синтезу білків, є важливими біологічними об 'єктами, які допомагають підтримувати загальний стан здоров'я людини, беруть участь у рості і розвитку організму, функиіонуванні клітинного метаболізму. За рахунок здатності підтримувати рівновагу між анаболітичним i катаболітичним метаболізмом промислові білки досягли статусу біологічно активного інгредієнта або речовини, щзо сприяє зміцненню здоров'я, яке пов'язане з розміщенням пептидів або амінокислот в ланцюгу, зашифрованих в кожному білку. У статті наведені дані досліджень щзодо вивчення впливу створеної білкововмісної функціональної композиції (БФК) заданого складу та властивостей на СКОР та показники біологічної ефективності білків варених ковбас. Біологічна ияінність як критерій оцінки білка має велике значення для визначення ефективності його використання організмом. Амінокислотний склад продукту є одним з пока-
} 
зників його біологічної иінності. В результаті аналізу отриманих даних щзодо вивчення амінокислотного складу дослідних зразків варених ковбас встановили, щь дослідні зразки з використанням БФК збалансовані за вмістом незамінних амінокислот порівняно із контрольним зразком. Для дослідного зразка № 1 із використанням БФК спільно з червоним м'ясом птиці порівняно з контрольним зразком збільшується кількість всіх незамінних амінокислот в середньому на 67,2\%. Для дослідного зразка № 2 із використанням БФК спільно з м'ясом птиці механічного обвалювання (МПМО) спостерігається зменшення кількості таких амінокислот, як лізин, валін, сірковмісні (порівняно з дослідним зразком № 1), СКОР для яких становить менше ніж 100\%. Розрахувавши показники біологічної цінності та порівняльної надлишковості, а також коефіцієнти розрізнення амінокислотного складу (КРАС) та утилітарності узагальнили вплив БФК на біологічну ефективність білка продукту. Використання БФК в технології варених ковбас в кількості 30\% збільиує біологічну иінність дослідних зразків в середньому на 3\%, коефіиієнт утилітарності-на 8 ,4\% та змениує показник порівняльної надлишковості в середньому на 50\%, КРАС - на 4\% порівняно з контрольним зразком. Заміна розробленою БФК у рецептурах варених ковбас м'ясної сировини підвищує та збалансовує амінокислотний склад дослідних зразків.

Ключові слова: біологічна ефективність білка, варені ковбаси, незамінні амінокислоти, білкововмісна функціональна композиція, біологічна иінність, білок.

\section{Вступ}

Найважливішими фізіологічними і біологічними властивостями, що відображають цінність їжі, є відповідність хімічної структури їі компонентів, а також збалансованість харчових елементів, а саме макро- i мікроелементів, вітамінів, амінокислот і т. д. (Strashynskyi et al., 2016).

Харчові білки, крім того, що використовуються як джерела енергії і забезпечують організм амінокислотами для синтезу білків, є важливими біологічними об'єктами, які допомагають підтримувати загальний стан здоров'я людини, беруть участь у рості та розвитку організму, функціонуванні клітинного метаболізмy (Hartmann \& Meisel, 2007; Tieland et al., 2012; Wolfe, 2015). В організмі людини білок допомагає підтримувати рівновагу між анаболічним і катаболітичним метаболізмом, і будь-яка тривала втрата білка в організмі відіграє центральну роль у розвитку багатьох проблем зі здоров'ям. За рахунок цього промислові білки досягли статусу біологічно активного інгредієнта або речовини, що сприяє зміцненню здоров'я, яке пов'язане $з$ розміщенням пептидів або амінокислот в ланцюгу, зашифрованих в кожному білку (Hoffer, 2016).

В даний час пропонуються різні рекомендації щодо споживання білка, найбільш визнана рекомендована добова норма (RDA) становить 0,8 г/кг/день (Institute of Medicine, 2005). Деякі інші літературні джерела вказують на більш високий рівень RDA для білка 1 г/кг/день, особливо для таких груп населення, як вагітні жінки, немовлята, діти дошкільного віку і літні люди (Rahi et al., 2015). Інші автори зазначають, що для молодих людей норма споживання білка дорівнює 1-1,5 г білка (точніше - сума різних типів білків) в день на 1 кг маси тіла (дітям дещо більше). Середня добова фізіологічна потреба людини в білку згідно з даними досліджень (Alexandratos \& Bruinsma, $2003)$ в перерахунку на 1 кг маси тіла на добу у дорослої людини в середньому дорівнює близько 1,3 г, для дітей, залежно від віку, 1,5-4,0 г.

Формула збалансованого харчування для дорослої людини відображає його денну потребу в харчових речовинах. Науковці у своїх працях подають інформацію, що потреба білка становить 70-80 г в день, причому на частку тваринних білків повинно припадати не менше 55\%. Тваринні білки за своїм складом наближені до білків людини, тому з 100 г білка 60 г повинні складати саме вони (Durst et al., 2010). Осно- вними і звичними для людини джерелами повноцінного білка служать продукти тваринного походження.

Згідно з переглядом в 2012 році світового сільського господарства до 2030/2050 року - для задоволення харчування зростаючої чисельності населення загальний обсяг виробництва м'яса потрібно збільшить 3258 мільйонів тонн в 2005 році до 455 мільйонів тонн до 2050 року (Premalatha et al., 2011; Belluco et al., 2017). Аналогічні тенденції спостерігалися і для інших високоякісних джерел білка. Ці прогнози показують значне збільшення попиту на білок, для задоволення потреб зростаючої чисельності населення.

Білки рослинного і тваринного походження були i залишаються єдиним найпоширенішим і безпечним джерелом білкових сполук для організму людини. Проте вони містять незамінні амінокислоти в різній кількості і співвідношенні. Наприклад, тваринний білок $з$ плазми крові є повноцінним, тому що містить всі незамінні амінокислоти (Strashynskyi et al., 2016). Білки 3 колагену - неповноцінні. Соєві - збалансовані за амінокислотним складом щодо еталонного білка, але мають в недостатній кількості сірковмісні амінокислоти (Sforza et al., 2016).

Тому доцільно білкові препарати використовувати у вигляді бінарних і багатокомпонентних сумішей в певних співвідношеннях компонентів, що забезпечують взаємозбагачення за амінокислотним складом та модифікацію функціонально-технологічних властивостей (Pasichnyi et al., 2015). Крім того зі зростанням чисельності населення і потреби в білку необхідно шукати нові раціональні шляхи використання наявних ресурсів харчового білка. Для реалізації повного потенціалу альтернативних джерел білка як заміни м'яса в м'ясних продуктах необхідні подальші дослідження.

Метою дослідження є вивчення впливу створенної БФК певного складу та властивостей на СКОР та показники біологічної ефективності білків варених ковбас.

Відповідно до мети досліджень поставили ряд завдань, які полягають у дослідженні вмісту незамінних амінокислот у складі контрольного і дослідних зразків варених ковбас; розрахунку СКОР для даних амінокислот; розрахунку показників біологічної ефективності білків контрольного і дослідних зразків варених ковбас, а саме показника біологічної цінності, коефіцієнта розрізнення амінокислотного скору (КРАС), коефіцієнта утилітарності амінокислотного складу і показника порівняльної надлишковості. 


\section{Матеріал і методи досліджень}

Для удосконалення технології варених ковбасних виробів використали розроблену і досліджену білкововмісну функціональну композицію (БФК) із збалансованим амінокислотним складом в кількості $30 \%$ спільно із червоним курячим м'ясом для дослідного зразка № 1 та спільно 3 м’ясом птиці механічного обвалювання (МПМО) для дослідного зразка № 2 замість гідратованого соєвого білка і емульсії на основі свинячої шкурки і частини жирової сировини та вивчили безпосередній іiі вплив на амінокислотний склад білка дослідних зразків продукту та його біологічну ефективність, яка визначалась показниками біологічної цінності (БЦ), порівняльної надлишковості та коефіцієнтами розрізнення амінокислотного складу (КРАС) і утилітарності.

Виготовлення зразків варених ковбас проводили згідно зі стандартною технологією (Strashynskiy et al., 2016). Розрахунок наведених показників здійснювали за допомогою таких формул (Antipova et al., 2001; Holovko et al., 2011; Stetsenko et al., 2012):

- амінокислотний СКОР продукту $\left(\mathrm{C}_{\mathrm{j}}, \%\right)$ визначали за формулою:

$$
C j=\frac{A j}{A j e} \cdot 100
$$

де $\mathrm{A}_{\mathrm{j}}$ - вміст j-ї незамінної амінокислоти (НАК) в білку продукту, г/100 г білка; $\mathrm{A}_{\mathrm{je}}$ - вміст j-ї НАК в еталонному білку, г/100 г білка.

- коефіцієнт утилітарності (u, \%), який показує загальний рівень утилізації білка, розраховували за формулою:

$$
u=C \min \frac{\sum_{j=1}^{8} A j e}{\sum_{j=1}^{8} A j}
$$

де Cmin - СКОР першої лімітованої НАК, частка од.;
- коефіцієнт надлишковості незамінних амінокислот $\sigma_{\text {над }}$ визначали як масову частку НАК в 100 г білка продукту, яка використовується організмом нераціонально, за формулою:

$$
\sigma_{\text {над }}=\frac{\sum_{j=1}^{8}(A j-C \min \cdot A j e)}{C \min }
$$

- коефіцієнт КРАС, що показує середню величину надлишку амінокислотного скору НАК, за формулою:

$$
\begin{aligned}
K P A C & =\frac{\sum \triangle P A C}{n} \\
\triangle P A C & =C j-C \min
\end{aligned}
$$

де $\triangle \mathrm{PAC}$ - різниця амінокислотного скору; $\mathrm{n}$ - кількість незамінних амінокислот;

- біологічну цінність продукту БЦ, (\%) визначали за формулою:

БЦ $=100-$ КРАС

Після розрахунку даних показників зробили висновки щодо біологічної цінності білка варених ковбас.

\section{Результати та їх обговорення}

Біологічна цінність, як критерій оцінки білка має велике значення для визначення ефективності його використання організмом. Амінокислотний склад продукту є одним 3 показників його біологічної цінності.

Для визначення зміни амінокислотного складу залежно від рецептурного співвідношення інгредієнтів у складі варених ковбас був проведений амінокислотний аналіз контрольної та дослідних рецептур при різних співвідношеннях м'ясної сировини, БФК, МПМО. Амінокислотний склад білків визначали методом іонообмінної рідинно-колончатої хроматографії. На рисунку 1 наведені результати досліджень СКОРу незамінних амінокислот для контрольного та дослідних зразків варених ковбас.

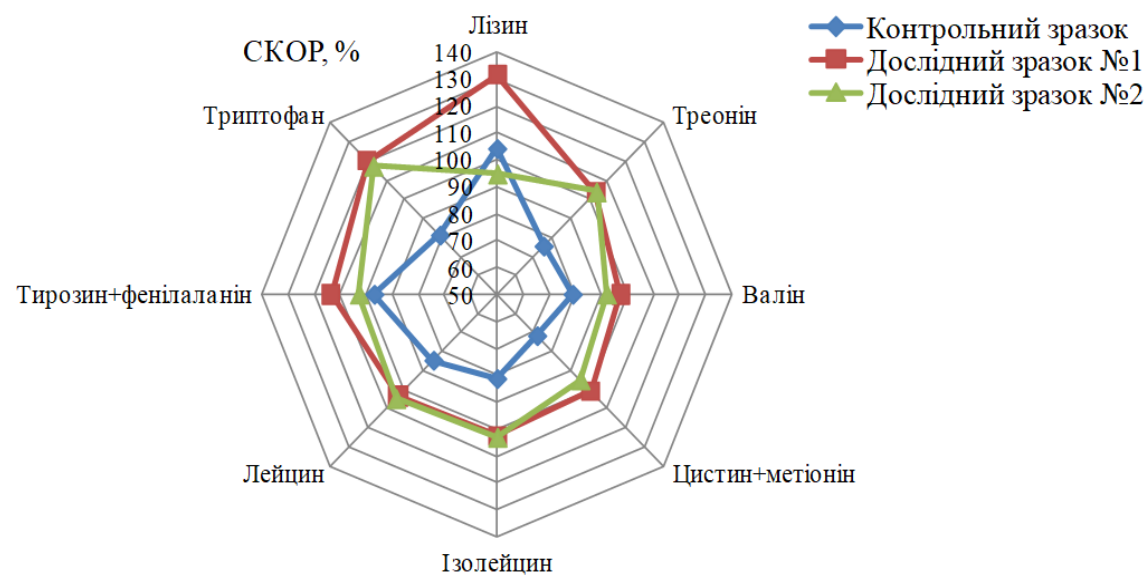

Рис. 1. СКОР незамінних амінокислот контрольного та дослідних зразків варених ковбас

Згідно $з$ даними у складі білка контрольного зразка в достатній кількості міститься незамінна амінокислота лізин. Для решти незамінних амінокислот значення СКОР - менше ніж $100 \%$, що свідчить про їхню недостатню кількість згідно з вимогами ФАО/ВООЗ для забезпечення потреб організму людини. Дані результати обгрунтовуються значною кількістю у складі зразка емульсії на основі свинячої шкурки, що, як відомо, характеризується незбалансованим вмістом амінокислот та переважною кількістю колагенових 
неповноцінних білків. Поряд з цим додавання гідратованих соєвих білків, які характеризуються підвищеною кількістю лізину, в кінцевому підсумку обумовило ії збільшення у вареній ковбасі.

Для дослідного зразка № 1 показник СКОР незамінних амінокислот складає: валін - 97\%, ізолейцин $102,5 \%$, лейцин - 103,4\%, тирозин і фенілаланін $113,3 \%$, лізин - 131,3\%, треонін - 103,5\%, цистин і метіонін - 100,6\%. Лімітованою амінокислотою в даному випадку є валін. СКОР всіх решти незамінних амінокислот понад 100\%. Порівнявши отримані дані 3 контрольною рецептурою, можна помітити збільшення кількості незамінних амінокислот до встановленого рівня відповідно до потреб людини та збалансування їх кількості, про що свідчить показник КРАС для зразка наведений у таблиці 1. Для даного зразка порівняно з контрольним збільшується кількість всіх незамінних амінокислот в середньому на 67,2\%. На отримані дані значною мірою вплинуло збільшення кількості м'ясної сировини за рахунок внесення червоного м'яса птиці та використання розробленої БФК зі збалансованим амінокислотним складом. Для дослідного зразка № 1 характерне значне збільшення кількості лізину порівняно з контрольним зразком, що обумовлено використанням м'яса птиці, яке характеризується високим вмістом даної амінокислоти та БФК, до складу якої входять соєві білки.

Для рецептури № 2 лімітованими амінокислотами $\epsilon$ лізин, СКОР якої складає 94,5\%, що менше порівняно 3 контрольним зразком на 9,1\%; валін - СКОР $91,8 \%$, що більше порівняно з контрольним зразком на 16\%, та сума сірковмісних - СКОР 94,86\% (більше на 33,4\% порівняно 3 контрольним). Порівняно $з$ рецептурою № 1 показники СКОРу для даних амінокислот зменшуються на 28\%, 5,3\%, 5,7\% відповідно. Для решти НАК СКОР складає понад 100\% і перебуває на рівні дослідного зразка № 1, що свідчить про їх достатній вміст у продукті.

\section{Таблиця 1}

Показники біологічної ефективності білків
Розрахунковим методом можна визначити індекс біологічної цінності, або амінокислотний СКОР (відношення скору білка продукту до СКОРу білка еталону). Біологічну цінність білка визначають за амінокислотним складом, порівнюючи його з амінокислотним складом “ідеального білка", запропонованого ФАО/ВООЗ. Для оцінки ступеня використання білка розраховується коефіцієнт розрізнення амінокислотного скору (КРАС) - це різниця амінокислотного скору незамінних амінокислот і скору амінокислоти, що лімітує. Середнє значення (КРАС) знаходили, як середнє арифметичне (КРАС) незамінних амінокислот указаного продукту. Чим менше значення КРАС, тим повніше в продукті використовуються амінокислоти. Коефіцієнт збалансованості амінокислотного складу (коефіцієнт утилітарності) чисельно характеризує збалансованість незамінних амінокислот стосовно до фізіологічно необхідної норми (еталону). Протилежною характеристикою утилітарності є показник порівняльної надлишковості. Даний показник характеризує загальну кількість незамінних амінокислот, які не використовуються на анаболітичні цілі, в такій кількості білка дослідного продукту, яка еквівалентна за їх потенційною утилітарністю вмісту в 100 г білкаеталону. Якісна оцінка дослідних білків за допомогою наведених показників полягає у тому, що чим вище значення утилітарності або менше значення показника порівняльної надлишковості (в ідеальному зразку утилітарність дорівнює 1 , а надлишковість - 0), тим краще збалансовані незамінні амінокислоти і тим раціональніше вони можуть бути використані організмом.

Щоб оцінити харчову адекватність білкових компонентів нової продукції щодо ступеня іiї засвоюваності, розраховані показники та критерії біологічної цінності білка, наведені в таблиці 1.

\begin{tabular}{lccc}
\multicolumn{1}{c}{ Показник } & $\begin{array}{c}\text { Контрольний } \\
\text { зразок }\end{array}$ & $\begin{array}{c}\text { Дослідний зразок } \\
\text { № 1 }\end{array}$ & $\begin{array}{c}\text { Дослідний зразок } \\
\text { № 2 }\end{array}$ \\
\hline Коефіцієнт розрізнення амінокислотного скору & 12,53 & 11,95 & 9,73 \\
незамінних і лімітованої амінокислот (КРАС), \% & 87,47 & 88,05 & 90,27 \\
Біологічна цінність (БЦ), \% & 0,83 & 0,89 & 0,91 \\
Коефіцієнт утилітарності амінокислотного складу & 0,07 & 0,04 & 0,03 \\
Показник порівняльної надлишковості & & \\
\hline
\end{tabular}

Отримані дані свідчать, що дослідні зразки, у яких провели заміну частини м'ясної сировини збалансованою БФК, характеризуються низькими показниками розбалансованості амінокислотного складу і відповідно високими показниками біологічної цінності. Для дослідного зразка № 1 показник КРАС зменшується на 4,6\% порівняно з контрольним зразком; для дослідних зразків № 2 - на 3,2\%. Відповідно до цього збільшується БЦ на 0,6\% для дослідного зразка № 1 порівняно з контрольним зразком та на 3,2\% для дослідних зразків № 2. Аналіз отриманих даних дозволив встановити, що збільшення показника БЦ для дослід- них зразків $є$ незначним. Проте основною умовою, яка обгрунтовує доцільність використання в рецептурі 30\% БФК, є збільшення кількості незамінних амінокислот варених ковбас до рівня встановлених норм ФАО/ВООЗ для забезпечення добових потреб людини. Аналіз розрахованих даних щодо визначення утилітарності і порівняльної надлишковості амінокислотного складу продукту свідчить, що використання БФК у кількості 30\% разом з червоним курячим м'ясом збільшує коефіцієнт утилітарності на 7,2\% порівняно з контрольним зразком і становить 0,89 та зменшує показник надлишковості на $42,8 \%$ до рівня 
0,04. Для дослідного зразка № 2 з використанням БФК та МПМО коефіцієнт утилітарності збільшується на 9,6\% порівняно 3 контрольним зразком та на 2,2\% порівняно 3 дослідним зразком № 1 і становить 0,91; відповідно показник порівняльної надлишковості зменшується на 57,1\% порівняно 3 контрольним зразком та на $25 \%$ порівняно із дослідним зразком № 1 та перебуває на рівні 0,03. Отримані дані свідчать про кращу збалансованість незамінних амінокислот у складі дослідних зразків вареної ковбаси порівняно контрольним та раціональніше їх використання організмом, оскільки відповідно до встановлених норм показник утилітарності наближається до 1, а показник надлишковості до 0. Проте незважаючи на найбільше наближення показників утилітарності та порівняльної надлишковості до оптимальних, даний зразок характеризується незбалансованістю амінокислотного складу через відсутність у встановленій кількості такої незамінної амінокислоти, як лізин, що негативно вплине на показники засвоюваності решти амінокислот даного продукту.

\section{Висновки}

Отже, доходимо висновку, що заміна розробленою БФК у рецептурах варених ковбас м'ясної сировини поліпшує та збалансовує амінокислотний склад дослідних зразків (спостерігається збільшення вмісту всіх незамінних амінокислот). При заміні сировини, що входить до контрольної рецептури, БФК та червоним курячим м'ясом поряд з вищезазначеним спостерігається збільшення кількості такої незамінної амінокислоти як лізин. Враховуючи високі ФТВ та СМВ, амінокислотний склад дослідних зразків № 1, № 2 можна констатувати досягнення поставленої мети, яка полягала у створенні БФК заданого складу та властивостей для коригування ФТВ, фізико-хімічних властивостей варених ковбас з метою створення якісної, економічно доступної та збалансованої за амінокислотним складом продукції.

Перспективи подальших досліджень полягають у вивченні впливу розробленої і дослідженої БФК на показники перетравлюваності дослідних зразків варених ковбас.

\section{References}

Alexandratos, N., \& Bruinsma, J. (2003). World Agriculture: Towards 2015/2030: an FAO Perspective. Land Use Policy, 20(4), 375. http://www.fao.org/3/ay4252e.pdf.

Antipova, L.V., Glotova, I.A., \& Rogov, I.A. (2001). Metody issledovaniya myasa i myasnyh produktov. Kolos: Moskva (in Russian).

Belluco, S., Halloran, A., \& Ricci, A. (2017). New protein sources and food legislation: The case of edible insects and EU Law. Food Secur, 9, 803-814. doi: 10.1007/s12571-017-0704-0.

Durst, P.B., Johnson, D.V., Leslie, R.N., \& Shono, K. (2010). Forest insects as food: human bite back. Food and Agriculture Organization of the United Nations
Regional Office for Asia and the Pacific. Bangkok: Thailand.

Hartmann, R., \& Meisel, H. (2007). Food-derived peptides with biological activity: from research to food applications. Curr. Opin. Biotechnol, 18(2), 163-169. doi: 10.1016/j.copbio.2007.01.013.

Hoffer, L.J. (2016). Human protein and amino acid requirements. JPEN: J. Parenter. Enter. Nutr., 40(4), 460-474. doi: 10.1177/0148607115624084.

Holovko, M.P., Kolesnyk, T.L., \& Kolesnyk, A.O. (2011). Vplyv ioniv kaltsiiu napivfabrykatu kistkovoho kharchovoho na peretravliuvanist bilkiv miasnykh sichenykh vyrobiv. Prohresyvni tekhnika ta tekhnolohii kharchovykh vyrobnytstv restorannoho hospodarstva i torhivli, 2, 227-233 (in Ukrainian).

Institute of Medicine (2005). Dietary reference intakes for energy, carbohydrate, fiber, fat, fatty acids, cholesterol, protein, and amino acids. Washington, DC: The National Academies Press. doi: 10.17226/10490.

Pasichnyi, V.M., Strashynskyi, I.M., \& Fursik, O.P. (2015). Reolohichni vlastyvosti hidratovanykh bilokvmisnykh funktsionalnykh kharchovykh kompozytsii. Visnyk Natsionalnoho tekhnichnoho universytetu "Kharkivskyi politekhnichnyi instytut" Seriia: "Novi rishennia v suchasnykh tekhnolohiiakh", 62(1171), 166-170 (in Ukrainian).

Premalatha, M., Abbasi, T., Abbasi, T., \& Abbasi, S.A. (2011). Energy-efficient food production to reduce global warming and ecodegradation: The use of edible insects. Renewable and Sustainable Energy Reviews, 15(9), 4357-4360. doi: 10.1016/j.rser.2011.07.115.

Rahi, B., Morais, J.A., Gaudreau, P., Payette, H., \& Shatenstein, B. (2015). Energy and protein intakes and their association with a decline in functional capacity among diabetic older adults from the NuAge cohort. Eur. J. Nutr., 55(4), 1729-1739. doi: 10.1007/s00394015-0991-1.

Sforza, S., Tedeschi, T., \& Wierenga, P.A. (2016). Proteins: chemistry, characterization, and quality. In Encyclopedia of Food and Health; Caballero, B., Finglas, P.M., Toldrá, F. Eds.; Oxford: Academic Pres, 4, 548553.

Stetsenko, N.O., Hoiko, I.Iu., \& Raichuk, N.M. (2012). Multyzlakovi plastivtsi pidvyshchenoi kharchovoi tsinnosti z antyoksydantnymy vlastyvostiamy. Kharchova Nauka i Tekhnolohiia, 18, 31-35 (in Ukrainian).

Strashynskiy, I., Fursik, O., Pasichniy, V., Marynin, A., \& Goncharov, G. (2016). The study of properties of minces in boiled sausage with runctional food composition use. Eureka: Life Sciences. Food Science and Technology, 6, 31-36. doi: 10.21303/25045695.2016 .00238 .

Strashynskiy, I., Fursik, O., Pasichniy, V., Marynin, A., \& Goncharov, G. (2016). Influence of functional food composition on the properties of meat mince systems. Eastern-European Journal of Enterprise Technologies. (Technology and Equipment of Food Production), 6, 11(84), 53-58. doi: 10.15587/1729-4061.2016.86957.

Strashynskyi, I.M., Pasichnyi, V.M., \& Fursik, O.P. (2016). Vyznachennia aminokyslotnoho skladu ta mikrobiolohichnykh pokaznykiv varenykh kovbas. 
Naukovyi visnyk LNUVMBT imeni S.Z. Hzhytskoho, 18, 2(68), 115-120. doi: $10.15421 /$ nvlvet6823 (in Ukrainian).

Tieland, M., Borgonjen-Van Den Berg, K.J., Van Loon, L.J.C., \& De Groot, L.C.P.G.M. (2012). Dietary protein intake in community-dwelling, frail, and institu- tionalized elderly people: scope for improvement. Eur. J. Nutr, 51(2), 173-179. doi: 10.1007/s00394-0110203-6.

Wolfe, R.R. (2015). Update on protein intake: importance of milk proteins for health status of the elderly. Nutr. Rev, 73(1), 41-47. doi: 10.1093/nutrit/nuv021. 